\title{
Sense of belonging as an indicator of social capital
}

Ahn, Mi Young; Davis, Howard

\section{International Journal of Sociology \& Social Policy}

DOI:

https://doi.org/10.1108/IJSSP-12-2019-0258

Published: 13/07/2020

Peer reviewed version

Cyswllt i'r cyhoeddiad / Link to publication

Dyfyniad o'r fersiwn a gyhoeddwyd / Citation for published version (APA):

Ahn, M. Y., \& Davis, H. (2020). Sense of belonging as an indicator of social capital. International Journal of Sociology \& Social Policy, 40(7/8), 627-642. https://doi.org/10.1108/lJSSP-12-20190258

\section{Hawliau Cyffredinol / General rights}

Copyright and moral rights for the publications made accessible in the public portal are retained by the authors and/or other copyright owners and it is a condition of accessing publications that users recognise and abide by the legal requirements associated with these rights.

- Users may download and print one copy of any publication from the public portal for the purpose of private study or research.

- You may not further distribute the material or use it for any profit-making activity or commercial gain

- You may freely distribute the URL identifying the publication in the public portal ?

Take down policy

If you believe that this document breaches copyright please contact us providing details, and we will remove access to the work immediately and investigate your claim. 


\title{
Sense of belonging as an indicator of social capital
}

\author{
Miyoung Ahn and Howard Davis
}

\begin{abstract}
Purpose- This paper examines the possibility of using sense of belonging as an indicator for social capital. Social capital, from the collective social capital theory perspective, is constructed from three main elements: trust, social network and participation. Social capital is crucial to civil society and wellbeing, but there is no consensus on how to define and measure it. This paper approaches this problem with the different but related concept of sense of belonging, as belonging overlaps with social capital conceptually, but also is more amenable to measurement.
\end{abstract}

Design/methodology/approach- Qualitative and quantitative data was collected from approximately 800 university students and used to explore the relationship between belonging and social capital both conceptually and empirically in the higher education context.

Findings -The mixed methods research analysis in this paper provides strong evidence to show how sense of belonging and social capital are theoretically and empirically intertwined. Conceptually they occupy overlapping spheres and their connections can be clearly traced and measured. This is supported by substantial statistical evidence of their relatedness, despite their independent origins in social research. For these reasons, this paper argues that sense of belonging can be used as a simplified alternative way to measure social capital.

Originality/value- This paper explains the advantages of using sense of belonging to understand social capital. It sets out a conceptual framework and provides a statistical demonstration. This paper develops and enriches a current strand of social capital and sense of belonging research in the fields of sociology and higher education policy.

Key words: sense of belonging, social capital, social network, participation, higher education, mixed methods 


\section{Introduction}

Despite the rapid growth and widespread popularity of the concept (Portes, 2000; Woolcock, 2010), it is difficult to find a general consensus about the definition of social capital in academia and policy discourse (Schuller et al. 2000; Julien, 2015). Researchers using an individual perspective like Lin (2001) regard social capital as important and powerful resources embedded in networks which serve personal goals like jobs (Varekamp et al. 2015; Gayen et al. 2019), while collective theorists, mainly rooted in Putnam (1993, 2000), refer to social capital as a collective good coming from shared norms and values, trust, and reciprocity. It has been described as 'a wonderfully elastic term' (Lappe and DuBois, 1997:119), while other critics argue that the concept suffers from overuse as a universal remedy for a multitude of social problems in social policy (Foley and Edwards 1997; Portes, 1998; Woolcock, 1998; Macinko and Starfield 2001). This flexibility of the notion of social capital stretches definitions and interpretations (Schuller et al. 2000:25) and provokes epistemological and methodological disagreement between researchers (Patulny and Lind, 2007; Woolcock, 2010), or criticism for being tautological or empty rhetoric (Foley and Edwards 1997; Portes 1998; Schuller et al. 2000; Macinko and Starfield 2001; Julien 2015). Social capital is not a single, straightforward idea, but rather a melting pot which can allow various meanings in many different contexts (Son, 2015). The ambiguities are inevitably related to the measurement issues (Patulny and Lind, 2007; Dhakal, 2014). Indeed, the measurement of social capital is often regarded as the most critical weakness because it is problematic on the conceptual as well as empirical levels (Fukuyama, 2000). As Morrow (1999) argues, social capital can function effectively as metaphor, but it might not to be the most appropriate concept to measure.

This paper approaches this problem with the different but related concept of sense of belonging. Conceptually, sense of belonging shares many important features with social capital but lends itself to more precise measurement. The paper explores how sense of belonging is related to social capital in the higher education context, focusing on social network and participation as the theoretical linkage between them. It is also designed to investigate whether sense of belonging can be used as an indicator for measuring social capital, starting with a review of literature which contains explicit conceptual and empirical treatment of the relationship between social capital and belonging. 


\section{Relatedness between social capital and sense of belonging}

Many scholars have searched for clarity of definition and measurement, including Putnam (1993, 2000), Woolcock (1998), Paxton (1999), Burt (2000), Fukuyama (2001), and Lin (2001). Social capital debates, particularly collective social capital theory, which is fundamentally inspired by Putnam's neo-Tocquevillean conceptualisation of social capital and its position in civil society (Foley and Edwards, 1999; Morrow, 1999), have been formulated around three main components - trust, social network, and participation. They are presumed to contribute significantly to a healthy, happy, safe, and effective society (Fukuyama, 2000; Putnam, 2000; Woolcock, 2001; Helliwell and Putnam, 2004; Wallace and Pichler, 2009). Sense of belonging is generally defined as a feeling of ease, safety, being connected and respected (Yuval-Davis, 2006; May, 2013). It is the relational aspect of ontological security, which develops in everyday life on the personal level and links a person to society (Savage et al. 2005; Yuval-Davis, 2006; Antonsich, 2010; May, 2011, 2013).

Some researchers who adopt the social capital perspective seem uninterested in the role of belonging (Schaefer-McDaniel, 2004: 163), whereas others regard belonging as one component of social capital. For instance, Wellman and his colleagues consider sense of belonging to be quite an important element for generating social capital (Wellman et al., 2001). They argue that sense of belonging comes from social interactions between people, and it influences their participation in the community. Others use belonging as a key indicator to understand community activity (Zúñiga et al. 2012); social inclusion or exclusion (Morrow, 2001); community cohesion (Forrest and Kearns, 2001; Cheong et al. 2007); social network and cohesion (Paiva et al. 2014); participation (Chang and Chung, 2011); neighbourhoods (Office for National Statistics, 2015); and reciprocal help in neighbourhoods (Mata and Pendakur, 2014).

Instead of adopting the terminology of sense of belonging directly, some research, for instance, Paxton (1999), Wollebaek and Selle (2002), and Li et al. (2003, 2005), uses similar terms, namely neighbourhood or place attachment. Paxton (1999) develops her own measurement tool with three indicators: membership, socialising with neighbours, and friends. Similarly, Wollebaek and Selle (2002) focus on social network as one of three elements of social capital, which are described as neighbours, colleagues, and friends. Li and his colleagues $(2003,2005)$ understand neighbourhood attachment as weak ties, which features in a question about sense of belonging to an area. More rarely, belonging is regarded 
as significantly related to, but independent from, social capital (e.g. Zhao et al, 2012). The attempt to measure social capital within more tangible and visible boundaries such as neighbourhood and geographic location has led to the recent development of the concept of neighbourhood social capital (Nast and Blockland, 2014).

In health and psychology research, centring around the concept of community belonging, or sense of community, belonging is included and itemised to measure social capital (e.g. Lochner et al. 1999; Fujiwara et Kawachi 2008a \& 2008b). Two similar studies conducted by Pooley et al. (2005) and Young et al. (2004) in Australia focus on the relationship between social capital and sense of community or sense of belonging to a neighbourhood. Pooley et al. (2005) concludes that individuals' sense of community is significantly associated with social capital in the community and can, therefore, be employed as a useful indicator for social capital. However, it is difficult to distinguish the conceptual boundaries between social capital and community belonging in this context, since the concepts are too similar.

In higher education research, on the other hand, the conceptual boundary is relatively clear, since sense of belonging or sense of community is measured within the institution. Students' sense of belonging to their institution is defined as personal feelings of being related and connected to, and respected by the institution, or 'Psychological membership' (Goodenow, 1993). Many researchers argue that this belonging is crucial to students' wellbeing and success (Thomas, 2012). For the research investigating students' social capital and belonging, social capital is mainly taken to refer to resources embedded in the social networks (Lin, 2001), which are itemised as trust and social interaction with peers, and available support from them (e.g. Soria and Stebleton, 2013; Fearon et al., 2018; and O'Sullivan et al., 2019).

While there is almost an overabundance of literature on social capital and growing contributions to the study of belonging, there remains a significant gap in understanding. The relevant literature does not resolve the disagreements over the conceptual boundary of social capital and rarely suggests any alternative. It also does not explain whether belonging and social capital are overlapping but analytically distinct concepts, or whether, in terms of measurement, belonging is a more suitable semantic category for use in survey questions on social capital.

To answer these questions requires a research strategy and design that specifies the operational boundary of social capital based on its core components and focuses on the 
overlapping concepts between social capital and belonging. This paper, therefore, will explore how belonging is related to social capital, drawing on qualitative and quantitative data collected from participants in higher education. In doing so, this article seeks to examine to what extent belonging can be used as an indicator for social capital.

\section{The study}

The data derives from the Students' Sense of Belonging to Bangor University project (the Bangor research) which started out as an investigation of belonging in higher education, in response to the What Works? Student Retention \& Success programme (What Works programme) 2008-2011 ${ }^{\mathrm{i}}$. Unlike the What Works programme which focused on students' sense of belonging in the UK, this research contained a second research objective - to examine the possibility of using belonging as an indicator for social capital.

The Bangor research was conducted in 2014 and used qualitative and quantitative research to understand students' sense of belonging to their institution. A survey questionnaire was designed with 33 questions about levels of belonging, social capital, and demographic information, while an additional '10 Words Question' was developed to understand participants' own thoughts and feelings (Ahn, 2017). The latter instrument, based on free-text responses, uses a single open-ended question which invites participants to write down up to 10 words that come to mind when they think about their belonging to Bangor University (Ahn and Davis, 2019). It elicits responses in the form of single words and short phrases, and occasionally longer forms of text. In order to investigate the association between belonging and social capital, the questionnaire included variables for belonging in some key questions (University belonging, School belonging), social networks (interacting with fellow students, friends and lecturers, peer support, and numbers of close friends), participation (socialising with friends, participating in University clubs and society, and unpaid volunteer work including civic organisations), trust, and life satisfaction. Most variables were measured using Likert scales. Yet the design of the questions deliberately avoided using explicit terms from social capital theory and did not pre-judge the relative importance of sense of belonging.

A non-random sampling strategy was applied to recruit a purposive maximum-variation sample of students selected by age, socio-economic status, ethnicity and national identity. The data was collected from 806 participants between March and May 2014. The recruitment 
and data collection occurred in scheduled lectures to maximise the response rate. Taking part in the survey was completely voluntary and on the understanding that the data would be anonymous and held in strict confidence according to the university research ethics policy and guidelines.

Table 1 Profile of participants in the 10 Words Question and Survey questionnaire

\begin{tabular}{lcc}
\hline & 10 Words Question & Survey Questionnaire \\
\hline Total participants & 426 & 380 \\
Age (Mean) & $\mathrm{n} / \mathrm{a}^{*}$ & 23 \\
Gender (F/M) & $\mathrm{n} / \mathrm{a}$ & $242(63.7 \%) / 130(34.2 \%)$ \\
Ethnicity & $\mathrm{n} / \mathrm{a}$ & $294(77.4 \%)$ \\
(White-British) & & \\
Academic schools & Social sciences $87(20.4 \%)$ & Social Sciences $76(20.0 \%)$ \\
(top three) & Sports Sciences 56 (13.1\%) & Psychology 58 $(15.3 \%)$ \\
& Psychology 52 $(12.2 \%)$ & Healthcare $44(11.6 \%)$ \\
\hline
\end{tabular}

* To simplify the administration of the 10 Words Question, participants' demographic information was not collected.

Table 1 shows key demographic information available for the 806 participants, including their main academic disciplines. The 10 Words Question data was collected from 426 participants over 14 academic schools and analysed using sequential thematic analysis (initial scanning, systematic coding, and clustering) and frequencies. The quantitative data was collected from 380 participants in 16 academic schools. None of the total 806 participants took part in both surveys. Key variables were selected and examined using SPSS for exploratory factor analysis and correlation analysis in order to understand how trust, networks, participation, belonging, and life satisfaction are connected and influenced.

\section{Findings from the 10 Words Question}

\section{Conceptual relatedness between belonging and social capital}

Themes in the 10 Words Question data were identified by keywords and clusters through four analytic stages. Keywords were extracted and coded directly from responses, they were then 
grouped into a smaller number of themes based on their similarities and differences considering the higher education context. After repeated clustering, the thematic analysis led to four independent domains, which are considered to be the main spheres of students' sense of belonging in higher education. Details of this analysis procedure are reported in Ahn and Davis (2019).

In order to maintain methodological consistency, the analytic procedure applied to the belonging data exactly parallels the procedure applied to social capital. The responses were mapped separately into the domains found in the social capital literatures. The aim was to check the alignment between the main themes generated within each perspective. 
Table 2 Conceptual framework of the 82 keywords (middle) in the 10 Words data from the perspectives of belonging (left) and social capital (right)

\begin{tabular}{|c|c|c|c|c|}
\hline $\begin{array}{l}\text { Sense of belonging } \\
\text { domains }\end{array}$ & $\begin{array}{l}\text { Sense of belonging } \\
\text { sub-domains }\end{array}$ & Overlapping keywords and categories & Social capital themes & $\begin{array}{l}\text { Social capital } \\
\text { domains }\end{array}$ \\
\hline \multirow[t]{4}{*}{$\begin{array}{l}\text { Academic } \\
\text { engagement }\end{array}$} & Higher education & $\begin{array}{l}\text { Education purpose (education, degree, career, future, graduation) } \\
\text { Important (important) }\end{array}$ & Individual social capital & Associated \\
\hline & \multirow[t]{3}{*}{ University } & Curriculum (lecture, knowledge) & Not included & Not included \\
\hline & & University (university, school, service, building, logo) & Trust in institution & Trust \\
\hline & & Lecturer (lecturer, tutor) & \multirow[t]{2}{*}{ Social relations } & \multirow[t]{2}{*}{ Social network } \\
\hline \multirow[t]{6}{*}{ Social engagement } & \multirow[t]{2}{*}{ Friends } & $\begin{array}{l}\text { Friends (friends, mates, people), Socialising (social), Pubs (pubs), } \\
\text { Friendship (friendship, relationship) }\end{array}$ & & \\
\hline & & Friendship (confidence, trust) & Trust in others & Trust \\
\hline & Participation & $\begin{array}{l}\text { Participation (representing, participation, opportunity, volunteering, student } \\
\text { union) }\end{array}$ & $\begin{array}{l}\text { Instrumental } \\
\text { participation }\end{array}$ & \multirow[t]{2}{*}{ Participation } \\
\hline & Society & Clubs \& societies (societies, activities) & Expressive participation & \\
\hline & Network & Communication (communication) & Network & Social network \\
\hline & Solidarity & $\begin{array}{l}\text { Community feeling (involved, connected, community, belonging, together, } \\
\text { home, friendly, accessible, close, open), Support (support), Team (team) }\end{array}$ & $\begin{array}{l}\text { Community feelings \& } \\
\text { support }\end{array}$ & \multirow[t]{4}{*}{ Associated } \\
\hline \multirow[t]{2}{*}{ Surroundings } & Living space & Accommodation (halls) & \multirow{2}{*}{$\begin{array}{l}\text { Perception of locality \& } \\
\text { Surroundings }\end{array}$} & \\
\hline & $\begin{array}{l}\text { Geographical \& } \\
\text { cultural location }\end{array}$ & $\begin{array}{l}\text { Locality (natural environment, atmosphere, local, wales, small, old), } \\
\text { Culture (culture, language, international) }\end{array}$ & & \\
\hline \multirow[t]{6}{*}{ Personal space } & \multirow[t]{2}{*}{ Life attitudes } & Pride (pride), Respect (respect, equality, diversity) & Shared value & \\
\hline & & $\begin{array}{l}\text { Attitudes towards goals (commitment, passion, encouragement, } \\
\text { development, achievement), Challenge (challenge, change, different), } \\
\text { Independence (independence, freedom) }\end{array}$ & Not included & Not included \\
\hline & \multirow[t]{2}{*}{ Life satisfaction } & $\begin{array}{l}\text { Satisfaction (happy, secure, nice) } \\
\text { Dissatisfaction (isolated, stress, unhappy) }\end{array}$ & Life satisfaction & $\begin{array}{l}\text { Life } \\
\text { satisfaction } \\
\end{array}$ \\
\hline & & Living essentials (money, food, time, life human) & Not included & \multirow[t]{3}{*}{ Not included } \\
\hline & Identity & Student (student, experience) & Not included & \\
\hline & Personal interest & Personal interest (hobby) & Not included & \\
\hline
\end{tabular}


Table 2 shows the results of the synthesis of the two perspectives. On the left side, there are the four main domains of sense of belonging: academic and social engagement, surroundings, and personal space, containing 13 inductively-derived sub-domains (Ahn and Davis, 2019:5). The middle column of the table contains the data from the 10 Words Question. These keywords are grouped into categories, which correspond to the social capital terms on the right side. These social capital themes include core components such as trust in others and institutions, various forms of social network, instrumental and expressive participation, associated concepts. The data which has little relevance to social capital analysis (e.g. curriculum, students' lifestyle, and personal interest) are marked as 'Not included'. The table highlights how sense of belonging can be both conceptually and empirically linked to social capital. On the left side, the four domains are derived from the data empirically, in a process designed to explore sense of belonging; whereas on the right side, the social capital themes resulted from a synthesis of the theoretical and empirical literatures ${ }^{\mathrm{ii}}$.

First, three main components of social capital, namely trust, network, and participation are strongly evident. Trust is expressed in terms which refer to personal and institutional attachment. Social network consists of various types and forms of social relations and activities, while participation includes expressive as well as instrumental actions. Arguably, only these three domains should be considered as components of social capital in the restricted definition. On the other hand, the rest of the keywords were clustered as 'associated concepts' including five items: community feeling and support, the perception of locality and surroundings, shared value, individual social capital, and life satisfaction. Although they are less directly related to social capital, concepts such as community, locality, and value are often included in other research measuring social capital using the inclusive definition. As discussed in the literature review, the definition of social capital varies from being specific, particular and limited, to being open and applicable in a multitude of ways. Therefore, it is worth considering the more diffuse concepts, to see whether the results might differ from the restricted definition with three main components.

The 'Not included' section shows that some elements are irrelevant in the social capital context: mainly academic engagement and personal spaces. This is consistent with the conceptual argument that sense of belonging is not completely synonymous with social capital, as established in the linkage discussion. Life satisfaction is included, and treated as connected but independent, since both belonging and social capital are positively related to it, 
as the literature review established. In addition, life satisfaction is often used as a barometer to indicate the level of happiness and health of a society.

\section{Statistical approach}

Following the thematic analysis, the responses from the 426 participants from the 10 Words Question were sorted into the main components of social capital: trust, social network, participation, community feelings, surroundings, shared values, individual social capital, and life satisfaction. Table 3 summarises the results of a frequency count of participants, who provided any relevant responses in each category of social capital. The most frequently mentioned category was social network. Approximately 7 in 10 participants (294 participants, $69.0 \%$ ) wrote down one or more responses related to social network; followed by participation (255 participants, 59.9\%), community (214 participants, 50.2\%) and surroundings (208 participants, 48.8\%).

Table 3 Frequency of responses for each category of social capital

\begin{tabular}{ccccccccc}
\hline & Trust & $\begin{array}{c}\text { Social } \\
\text { network }\end{array}$ & Participation & Community & Surroundings & $\begin{array}{c}\text { Shared } \\
\text { value }\end{array}$ & $\begin{array}{c}\text { Individual } \\
\text { Life }\end{array}$ \\
\hline Yes & 154 & 294 & 255 & 214 & 208 & 48 & 62 & 124 \\
& $(36.2)$ & $(69.0)$ & $(59.9)$ & $(50.2)$ & $(48.8)$ & $(11.3)$ & $(14.6)$ & $(29.1)$ \\
No & 272 & 132 & 171 & 212 & 218 & 378 & 364 & 302 \\
& $(63.8)$ & $(31.0)$ & $(40.1)$ & $(49.8)$ & $(51.2)$ & $(88.7)$ & $(85.4)$ & $(70.9)$ \\
\hline
\end{tabular}

The analysis shows that $82.4 \%$ of the total 426 responses were relevant to three core components (trust, social network and participation). Due to the conceptual difference between social capital and belonging, the reduction in frequency of the relevant data from $100 \%$ to $82.4 \%$ was anticipated. But a more inclusive definition of social capital subsumes virtually every participant (99.1\%) and the differences between social capital and belonging perspectives appear less significant and even marginal. This is the crucial evidence that the belonging data can be effectively used to understand social capital. 


\section{Findings from quantitative research- Survey questionnaire analysis}

In order to explore how all the variables from the survey questionnaire were related, a

Principal Component Analysis (PCA) was conducted on the 21 items with oblique rotation (direct oblimin). The Kaiser-Meyer-Olkin measure verified the sampling adequacy for the analysis, $\mathrm{KMO}=0.86$, and all $\mathrm{KMO}$ values for individual items were greater than 0.79 , which is well above the acceptable limit of 0.5. Five factors had eigenvalues over Kaiser's criterion of 1 and in combination explained $61.15 \%$ of the variance. Table 4 shows the complete PCA results including factor loadings after rotation, eigenvalues, Cronbach's $\alpha$, communalities, and means (M) with standard deviations (SD). The five factors extracted by the PCA are labelled as Socialising, Institutional belonging, Voluntary work, Social engagement, and Satisfaction \& trust, which have moderate to high reliabilities (between 0.72 and 0.83 ), and one factor with lower Cronbach's $\alpha$ (Voluntary work= 0.56 ).

Table 4 Summary of exploratory factor analysis results for social capital $(\mathrm{N}=336)$

\begin{tabular}{|c|c|c|c|c|c|c|c|}
\hline & Factor loa & dings & & & & & \\
\hline & Socialising & $\begin{array}{c}\text { Institutional } \\
\text { Belonging }\end{array}$ & $\begin{array}{c}\text { Voluntary } \\
\text { work }\end{array}$ & $\begin{array}{c}\text { Social } \\
\text { engagement }\end{array}$ & $\begin{array}{c}\text { Satisfaction } \\
\quad \& \text { trust }\end{array}$ & $\begin{array}{l}\text { Mean } \\
(\mathrm{SD})\end{array}$ & $\begin{array}{l}\text { Com } \\
\text { muna } \\
\text { lities }\end{array}$ \\
\hline Visit nightclubs & .83 & & & & & $\begin{array}{c}2.69 \\
(1.206)\end{array}$ & .70 \\
\hline Visit the pub & .83 & & & & & $\begin{array}{c}3.06 \\
(1.167)\end{array}$ & .73 \\
\hline Socialising with friends & .75 & & & & & $\begin{array}{c}4.95 \\
(1.030)\end{array}$ & .59 \\
\hline Visit friends' homes/halls & .64 & & & & & $\begin{array}{c}3.53 \\
(1.246)\end{array}$ & .47 \\
\hline $\begin{array}{l}\text { Enjoyable social life as a } \\
\text { student }\end{array}$ & .61 & & & & .42 & $\begin{array}{c}3.75 \\
(1.152)\end{array}$ & .74 \\
\hline Facebook/other SNSs & .44 & & & & & $\begin{array}{c}5.33 \\
(1.167)\end{array}$ & .29 \\
\hline Number of close friends & .37 & .34 & & & & $\begin{array}{l}3.82 \\
(.878)\end{array}$ & .46 \\
\hline University belonging & & -.78 & & & & $\begin{array}{c}3.96 \\
(1.020)\end{array}$ & .76 \\
\hline Academic school belonging & & -.61 & & .41 & & $\begin{array}{l}4.03 \\
(.951)\end{array}$ & .73 \\
\hline Students Union & & & .76 & & & $\begin{array}{l}1.51 \\
(.999)\end{array}$ & .61 \\
\hline Unpaid volunteer work & & & .76 & & & $\begin{array}{c}1.90 \\
(1.252)\end{array}$ & .56 \\
\hline University clubs \& societies & .38 & & .52 & & & $\begin{array}{l}2.53 \\
(1.457)\end{array}$ & .58 \\
\hline Supportive fellow students & & & & .79 & & $\begin{array}{l}4.19 \\
(.926)\end{array}$ & .70 \\
\hline Talking to fellow students & & & & .79 & & $\begin{array}{c}4.34 \\
(.913)\end{array}$ & .71 \\
\hline
\end{tabular}


Working with other students

Talking to lecturers

.49

Life satisfaction

Trust people

Life satisfaction as a student

$-.34$

.62

Eigenvalues

5.74

2.36

1.46

3.97

$\%$ of variance

30.19

12.43

7.70

1.05

1.02

$\alpha$

Table 5 Correlation analysis of factor scores from five factors

\begin{tabular}{lcccc}
\hline & $\begin{array}{c}\text { Institutional } \\
\text { belonging }\end{array}$ & $\begin{array}{c}\text { Voluntary } \\
\text { work }\end{array}$ & $\begin{array}{c}\text { Social } \\
\text { engagement }\end{array}$ & $\begin{array}{c}\text { Satisfaction \& } \\
\text { trust }\end{array}$ \\
\hline Socialising & & $\mathbf{. 2 2 7}^{* *}$ & $\mathbf{. 2 3 1}^{* *}$ & $\mathbf{. 2 3 6}^{* * *}$ \\
Institutional belonging & & $\mathbf{. . 1 3 6}^{*}$ & $\mathbf{. 1 3 7}^{*}$ & $\mathbf{. . 1 9 6}^{* *}$ \\
Voluntary work & & & & $\mathbf{. 2 3 9}^{* *}$ \\
Social engagement & & & & $\mathbf{. 3 7 3}^{* *}$ \\
\hline
\end{tabular}

**. Correlation is significant at the 0.01 level (2-tailed).

*. Correlation is significant at the 0.05 level (2-tailed).

Next, the correlation coefficient was calculated for these five factors. The results in Table 5 reveal that most factors are significantly correlated with each other, although the range of the strengths vary from weak to moderate. The social engagement factor represents social interaction and social support within the institution, which is associated with the life satisfaction and trust factor $(\mathrm{r}=0.373)$.

\section{Discussion}

This paper seeks to address the relatedness between sense of belonging and social capital by applying both qualitative and quantitative approaches. It should be highlighted that the data was collected for sense of belonging, not for social capital. The intention in this article is to examine the possibility of applying belonging as an indicator for measuring social capital. Social capital as a metaphor, is implicative and abstract; not a precise measurement tool. Belonging, however, is more a concrete and tangible concept that lends itself to 
measurement. The topic, sense of belonging, involves the type of question which can be asked directly. It requires little background knowledge and information, unlike complicated concepts or specific policies, for which participants might need substantial literacy, personal interest or professional knowledge. It is a relatively straightforward, common-sense theme, which appears casually in everyday settings, but with enough complexity to be worth exploring. An open-ended question can, therefore, act as a stimulus to reflect and express participants' experiences and views.

This paper concentrates on sense of belonging in a single higher educational context, which gives clarity to the geographical, cultural and organisational boundary of belonging. The cultural boundary based on the natural environment and geographic location is one of the crucial factors in belonging. For instance, this element can be expressed in various forms such as locality, regional culture, history, language and heritage (Ahn and Davis, 2019). As many sociologists argue (Savage et al. 2005; Antonsich, 2010; May, 2013; Benson and Jackson, 2013), these factors shape attachments to neighbourhood, spaces and surroundings. Lastly, the organisational boundary encompasses distinctive characteristics and atmospheres of each institution. Some consider this feature to be influential for organisational membership and participants' identities (Thomas, 2012). The boundary of 'the university' is methodologically useful to define and access members of the institution, which is the population for the data collection.

The main overlaps between the concepts of belonging and social capital were identified in the literature review as social networks and participation. For this paper, the elements of academic engagement (e.g. interactions with academic staff and fellow students in the teaching and learning environment) and social engagement (e.g. socialising with others, participating in various social activities including university clubs and societies, and numbers of close friends) in higher education are interpreted as equivalent to the network and participation components of social capital. For instance, Paxton (1999) and Li et al. (2005) developed items for their social capital questionnaires, in which informal socialising with either close friends or neighbours were measured separately. In the context of higher education, neighbourhood corresponds to social ties with fellow students and their emotional and physical support based on shared identity as members of the same institution. Trust is defined as strong belief and positive expectations of good will from people, institutions, and norms (Barber, 1983:165; Paxton, 1999;). Concrete and reciprocal social relationships 
generate trust in other individuals as well as the wider society. It was assumed that trust in institutions, or institutional trust (Kaasa, 2015), is already embedded and subsumed in belonging to the university, intrinsic to being a registered student, echoing Fukuyama's definition (1995:26).

The findings of this study support the conclusion that sense of belonging in higher education and social capital are substantially related. The thematic analysis of the 10 Words Question data reveals how the belonging data can be re-constructed to represent social capital, while the statistical approach to those themes helps to calculate the overlaps between the two concepts. The questionnaire data was statistically tested to examine to what extent belonging and social capital are associated. The findings align well with a small number of recent studies focusing on belonging and social capital in higher education (e.g. Soria and Stebleton, 2013; Fearon et al. 2018; O'Sullivan et al. 2019). For instance, the analysis of the Student Experience in the Research University survey in USA in 2010 confirms that social capital of the working-class students is positively correlated with sense of belonging and academic engagement (Soria and Stebleton, 2013). Another study investigating the widening access policy in the UK concludes that students' social network and interaction, as a form of social capital, plays an important role on their belonging (O'Sullivan et al. 2019). In the other study focusing on UK higher education (Fearon et al. 2018), the relationship between belonging and social capital was statistically tested, showing how it affects students' professional career.

The analysis of both the questionnaire and the 10 Words Question data reveals that life satisfaction is one of the vital elements for understanding belonging as well as social capital. Numerous pieces of research conclude that life satisfaction, or individual subjective wellbeing, is highly positively correlated to other elements such as social relations and interactions regarding the size and strength of social network (Helliwell and Putnam, 2004); sense of belonging (Toikko and Pehkonen, 2018); and volunteering and participation (Moen et al. 1993; Musick et al. 1999; Post, 2005; Meier and Stutzer, 2008; Wallace and Pichler, 2009; Plagnol and Huppert, 2010). In their influential paper, Helliwell and Putnam (2004) argue that there is a strong positive association between social capital and subjective wellbeing, when they assess them through key elements such as social network, social and civic participation, and trust. Our findings are consistent with their conclusions. 
Lastly, for this study, participation was considered as both social and civic participation. The term civic participation is defined as instrumental activities (Bekkers et al. 2008), rooted in Weber's typology (1922/1978), which is developed to explore functions and impacts of various social actions. In the higher education context, social participation is related to expressive purposes, for example in the context of clubs and societies in the university; and civic participation which explicitly stands for collective actions for the purpose of collective goals including volunteering, environmental organisations, and political parties ${ }^{\mathrm{iii}}$. The analysis of the questionnaire reveals relatively low levels of civic participation compared with other social activities such as socialising with friends, and visiting pubs. And it seems to have less associations with other elements.

However, the 10 Words analysis tells a different story. Evidence of civic action certainly exists in the belonging context. The category of 'instrumental participation' consists of relevant keywords such as 'representing', 'participation', 'volunteering' and 'student union'. According to the survey questionnaire analysis, students who do volunteering are more likely to have large social networks, strong social interaction and participation, higher belonging and life satisfaction. This finding is consistent with the previous research about the positive association between volunteering and belonging in secondary school (Wilson, 2012).

Volunteering, as one of the key elements of social capital (Putnam 2000; Halsall et al. 2016), tends to bridge other civic participation and various forms of social engagement. These findings correspond to many pieces of research about volunteering: the strong association between volunteering and other forms of social interaction (McPherson et al. 1992); general participation (Smith et al., 1980; Smith 1994); informal volunteering (Wallace and Pichler, 2009; Plagnol and Huppert, 2010); social network and participation (Wilson and Musick, 1997).

\section{Conclusion}

This paper set out to examine the possibility of using sense of belonging as an indicator for social capital. Due to its conceptual ambiguities and measurement difficulties, an operational definition of social capital was constructed from an analysis of the main concepts - trust, social network and participation - which then functioned as a platform for measurement. Sense of belonging, as personal feelings of being connected to others and groups, links a 
person to the society. In this paper belonging is defined and measured in the higher education context, which has the advantage of providing an unambiguous institutional boundary.

The mixed methods analysis in this paper has provided evidence to show how sense of belonging and social capital are theoretically and empirically intertwined. Conceptually they occupy overlapping spheres and their connections can be clearly traced and measured. There is also substantial statistical evidence of their relatedness, despite their independent origins in much social research. In particular, the conceptual framework was developed to demonstrate how the belonging data can be re-interpreted and re-applied to social capital in detail. It is applicable to the core components of social capital such as trust, social networks and participation, but also to the more inclusive definition.

For these reasons, this paper argues that sense of belonging can be used as a simplified alternative way to measure social capital. The case of student belonging is used as a clear demonstration but it is reasonable to propose that the approach and methods can be applied well beyond this institutional context. Investigating an alternative perspective of measuring social capital directly, this study will develop and enrich a current strand of social capital and sense of belonging research in sociology, higher education and policy fields.

\section{Acknowledgement}

Student's Sense of Belonging to Bangor University in 2014 was financially supported by Bangor University's Widening Access Fund (2013-2014). We would like to thank the student engagement office in Bangor University for support.

\section{References}

Ahn MY (2017) Sense of belonging as an indicator for social capital: a mixed methods analysis of students' sense of belonging to university. PhD diss. Prifysgol Bangor University. 
Ahn MY, Davis HH (2019) Four domains of students' sense of belonging to university. Studies in Higher Education 1-13 (accessed January 2019).

Antonsich M (2010) Searching for belonging-an analytical framework. Geography Compass 4(6):644-659.

Barber B (1983) The logic and limits of trust. New Brunswick, NJ: Rutgers University Press.

Bekkers R, Völker B, Van der Gaag M, and Flap H (2008) Social networks of participants in voluntary associations. Social Capital: An International Research Program: 185-205.

Benson M, Jackson E (2013) Place-making and place maintenance: Performativity, place and belonging among the middle classes. Sociology 47(4): 793-809.

Burt RS (2000) The network structure of social capital. Research in Organizational Behavior 22: $345-423$.

Chang HH, Chuang SS (2011) Social capital and individual motivations on knowledge sharing: Participant involvement as a moderator. Information \& management 48(1): 9-18.

Cheong PH, Edwards R, Goulbourne H, and Solomos J (2007) Immigration, social cohesion and social capital: A critical review. Critical social policy 27(1): 24-49.

Dhakal, SP (2014) A methodological framework for ascertaining the social capital of environmental community organisations in urban Australia. International Journal of Sociology and Social Policy, 34(11/12), 730-746.

Fearon, C., Nachmias, S., McLaughlin, H., \& Jackson, S. (2018). Personal values, social capital, and higher education student career decidedness: a new 'protean'-informed model. Studies in Higher Education, 43(2), 269-291.

Foley MW, Edwards B (1997) 'Escape from Politics? Social Theory and the Social Capital Debate'. American Behavioral Scientist 40: 550-61.

Forrest R, Kearns A (2001) Social cohesion, social capital and the neighbourhood. Urban studies 38(12): 2125-2143.

Fujiwara T, Kawachi I (2008a) Social capital and health: a study of adult twins in the US. American journal of preventive medicine, 35(2), 139-144.

Fujiwara T, Kawachi I (2008b) A prospective study of individual-level social capital and major depression in the United States. Journal of Epidemiology \& Community Health, 62(7), 627-633.

Fukuyama F (1995) Trust: The social virtues and the creation of prosperity (No. D10 $301 \mathrm{c}$. 1/c. 2). New York: Free Press Paperbacks.

Fukuyama F (2000) Social capital and civil society. Number 0-74. International Monetary Fund.

Fukuyama F (2001) Social capital, civil society and development. Third World Quarterly, 22(1):7-20. 
Gayen, K, Raeside, R, and McQuaid, R (2019) Social networks, accessed and mobilised social capital and the employment status of older workers: A case study. International Journal of Sociology and Social Policy, 39(5/6), 356-375.

Goodenow C (1993) The psychological sense of school membership among adolescents: Scale development and educational correlates. Psychology in the Schools, 30(1), 79-90.

Halsall, J, Cook, I, and Wankhade, P (2016) Global perspectives on volunteerism: Analysing the role of the state, society and social capital. International Journal of Sociology and Social Policy, 36(7/8), 456-468.

Helliwell JF, Putnam RD (2004) The social context of well-being. Philosophical Transactions-Royal Society of London Series B Biological Sciences, 1435-1446.

Julien C (2015) Bourdieu, social capital and online interaction. Sociology, 49(2):356-373.

Kaasa, A (2015) Culture, religion and social capital: evidence from European regions. International journal of sociology and social Policy, 35(11/12), 772-794.

Lappe FM, Du Bois PM (1997) Building social capital without looking backward. National Civic Review, 86(2), 119-128.

Li Y, Pickles A, and Savage M (2005) Social capital and social trust in Britain. European Sociological Review, 109-123.

Li Y, Savage M, and Pickles A (2003) Social capital and social exclusion in England and Wales (1972-1999). The British Journal of Sociology, 54(4):497-526.

Lin N, Cook KS, and Burt RS (2001) Social capital: Theory and research. Transaction Publishers.

Lochner K, Kawachi I, and Kennedy BP (1999) Social capital: a guide to its measurement. Health \& place, 5(4), 259-270.

Macinko J, Starfield B (2001) The utility of social capital in research on health determinants. The Milbank Quarterly, 79(3):387-427.

Mata F, Pendakur R (2014) Social capital, diversity and giving or receiving help among neighbours. Social Indicators Research, 118(1):329-347.

May V (2011) Self, belonging and social change. Sociology, 45(3), 363-378.

May V (2013) Connecting self to society: Belonging in a changing world. Palgrave Macmillan.

McMillan DW, Chavis DM (1986) Sense of community: A definition and theory. Journal of Community Psychology, 14(1):6-23.

McPherson JM, Popielarz PA, and Drobnic S (1992) Social networks and organizational dynamics. American Sociological Review, 153-170.

Meier S, Stutzer A (2008) Is volunteering rewarding in itself? Economica, 75(297), 39-59. 
Moen P, Dempster-McClain D, and Williams Jr RM (1992) Successful aging: A life-course perspective on women's multiple roles and health. American Journal of Sociology, 97(6), $1612-1638$.

Morrow V (1999) Conceptualising social capital in relation to the wellbeing of children and young people: a critical review. The Sociological Review, 47(4):744-765.

Morrow V (2001) Young people's explanations and experiences of social exclusion: retrieving Bourdieu's concept of social capital. International journal of sociology and social policy, 21(4/5/6), 37-63.

Musick MA, Herzog AR, and House JS (1999) Volunteering and mortality among older adults: Findings from a national sample. The Journals of Gerontology Series B:

Psychological Sciences and Social Sciences, 54(3), S173-S180.

Narayan D, Pritchett L (1999) Cents and sociability: Household income and social capital in rural Tanzania. Economic Development and Cultural Change, 47(4), 871-897.

Nast J, Blokland T (2014) Social mix revisited: Neighbourhood institutions as setting for boundary work and social capital. Sociology, 48(3), 482-499.

Office for National Statistics (2015) Measuring national well-being: An analysis of social capital in the UK. Available at:

https://www.ons.gov.uk/peoplepopulationandcommunity/wellbeing/articles/measuringnationa lwellbeing/2015-01-29.

O'Sullivan, K., Bird, N., Robson, J., \& Winters, N. (2019). Academic identity, confidence and belonging: The role of contextualised admissions and foundation years in higher education. British Educational Research Journal, 45(3), 554-575.

Paiva PCP, de Paiva HN, de Oliveira Filho PM, Lamounier JA, e Ferreira EF, Ferreira RC, and Zarzar PM (2014) Development and validation of a social capital questionnaire for adolescent students (SCQ-AS). PloS One, 9(8), e103785.

Patulny, R V and Lind Haase Svendsen, G (2007) Exploring the social capital grid: bonding, bridging, qualitative, quantitative. International Journal of Sociology and Social Policy, $27(1 / 2), 32-51$.

Paxton P (1999) Is social capital declining well in the united states? a multiple indicator assessment. American Journal of Sociology, 105(1):88-127.

Plagnol AC, Huppert FA (2010) Happy to help? Exploring the factors associated with variations in rates of volunteering across Europe. Social Indicators Research, 97(2): 157176.

Pooley JA, Cohen L, and Pike LT (2005) Can sense of community inform social capital? The Social Science Journal, 42(1), 71-79.

Portes A (1998) Social capital: Its origins and applications in modern sociology. Annual Review of Sociology, 24(1), 1-24. 
Portes A (2000) The two meanings of social capital. In Sociological forum (Vol. 15, No. 1, pp.1-12). Kluwer Academic Publishers-Plenum Publishers.

Post SG (2005) Altruism, happiness, and health: It's good to be good. International Journal of Behavioral Medicine, 12(2), 66-77.

Putnam RD (1993) The prosperous community. The American Prospect, 4(13), 35-42.

Putnam RD (2000) Bowling alone: America's declining social capital. New York: Palgrave Macmillan.

Savage M, Bagnall G, and Longhurst BJ (2005) Globalization and belonging. Sage.

Schaefer-McDaniel, N. J. (2004). Conceptualizing social capital among young people: Towards a new theory. Children youth and environments, 14(1), 153-172.

Schuller T, Baron S, and Field J (2000) Social capital: a review and critique. Social capital: Critical perspectives, 1-38.

Smith DH (1994) Determinants of voluntary association participation and volunteering: A literature review. Nonprofit and Voluntary Sector Quarterly, 23(3):243-263.

Smith DH, Macaulay J (1980) Participation in social and political activities. Jossey-Bass.

Son J (2015) Organizational social capital and generalized trust in Korea. American Behavioral Scientist, 59(8):1007-1023

Soria, K. M., \& Stebleton, M. J. (2013). Social capital, academic engagement, and sense of belonging among working-class college students. College Student Affairs Journal, 31(2), 139.

Thomas L (2012) Building student engagement and belonging in higher education at a time of change. Paul Hamlyn Foundation.

Toikko, T and Pehkonen, A (2018) Community belongingness and subjective well-being among unemployed people in a Finnish community. International Journal of Sociology and Social Policy, 38(9/10), 754-765.

Varekamp, I, Knijn, T, van der Gaag, M, and Bos, P (2015) Social capital and job search behaviour of long-term welfare recipients. International Journal of Sociology and Social Policy, 35(11/12), 738-755.

Wallace C, Pichler F (2009) More participation, happier society? A comparative study of civil society and the quality of life. Social indicators research, 93(2), 255-274.

Weber M (1922/1978) Economy and society: An outline of interpretive sociology. University of California Press.

Wellman B, Haase AQ, Witte J, and Hampton K (2001) Does the Internet increase, decrease, or supplement social capital? Social networks, participation, and community commitment. American Behavioral Scientist, 45(3), 436-455. 
Wilson J (2012) Volunteerism research: A review essay. Nonprofit and Voluntary Sector Quarterly, 41(2), 176-212.

Wilson J, Musick M (1997) Who cares? toward an integrated theory of volunteer work. American Sociological Review, 62, 694-713.

Wollebaek D, Selle P (2002) Does participation in voluntary associations contribute to social capital? The impact of intensity, scope, and type. Nonprofit and voluntary sector quarterly, 31(1), 32-61.

Woolcock M (1998) Social capital and economic development: Toward a theoretical synthesis and policy framework. Theory and Society, 27(2):151-208

Woolcock M (2010) The rise and routinization of social capital, 1988-2008. Annual Review of Political Science, 13:469-487.

Young AF, Russell A, and Powers JR (2004) The sense of belonging to a neighbourhood: can it be measured and is it related to health and well being in older women? Social Science \& Medicine, 59(12), 2627-2637.

Yuval-Davis N (2006) Belonging and the politics of belonging. Patterns of Prejudice, 40(3), 197-214.

Zhao L, Lu Y, Wang B, Chau PY, and Zhang L (2012) Cultivating the sense of belonging and motivating user participation in virtual communities: A social capital perspective. International Journal of Information Management, 32(6), 574-588.

Zúñiga H, Jung N, and Valenzuela S (2012) Social media use for news and individuals' social capital, civic engagement and political participation. Journal of Computer-Mediated Communication, 17(3), 319-336.

\footnotetext{
${ }^{i}$ What Works? Student Retention \& Success programme 2008-2011 was conducted to explore the evidence of effective practices linked to higher completion rates in the UK (Thomas, 2012). Findings from this programme influenced the present study, especially regarding the research design, survey questionnaire items, and data collection methods.

\begin{abstract}
${ }^{\text {ii }}$ Highlighting these distinctions in the conceptual framework is important, because the results could have been otherwise. For instance, if a theoretical approach was applied to both belonging and social capital, the framework might appear differently. It would not include four domains, but only the two domains of academic and social engagement, since these are the two categories highlighted in the existing literature about belonging in higher education (Ahn and Davis 2019). We found that they are not an adequate basis for understanding the relationship between belonging and social capital.

iii The civic participation variables in the survey questionnaire were adapted from the European Social Survey to enhance their reliability. The analysis needs to address the uncertainty whether civic participation is meaningfully associated with other variables, particularly with belonging. The table below shows that the internal associations between civic participation variables on both general and higher education contexts clearly exist, with an acceptable reliability level (Cronbach's $\alpha=0.6$ ).
\end{abstract}




\begin{tabular}{|c|c|c|c|c|c|c|c|c|}
\hline & $\begin{array}{l}\text { Volunteer } \\
\text { work }\end{array}$ & $\begin{array}{l}\text { Business } \\
\text { org }\end{array}$ & $\begin{array}{l}\text { Trade } \\
\text { union }\end{array}$ & $\begin{array}{l}\text { Student } \\
\text { union }\end{array}$ & $\begin{array}{l}\text { Humanitarian } \\
\text { org }\end{array}$ & $\begin{array}{l}\text { Environmental } \\
\text { org }\end{array}$ & $\begin{array}{l}\text { Political } \\
\text { party }\end{array}$ & $\begin{array}{l}\text { Religious } \\
\text { org }\end{array}$ \\
\hline $\begin{array}{l}\text { University } \\
\text { clubs \& } \\
\text { societies }\end{array}$ & $.264^{* *}$ & & & $.422^{* *}$ & $.134^{*}$ & $.144^{* * *}$ & $.111^{*}$ & \\
\hline $\begin{array}{l}\text { Volunteer } \\
\text { work }\end{array}$ & & $.278^{* *}$ & $.194^{* *}$ & $.237^{* *}$ & $.226^{* *}$ & $.288^{* *}$ & $.222^{* *}$ & $.140^{* *}$ \\
\hline Business org & & & $.296^{* *}$ & $.214^{* *}$ & $.265^{* *}$ & $.184^{* *}$ & $.157^{* *}$ & \\
\hline Trade union & & & & $.321^{* *}$ & $.233^{* *}$ & $.318^{* *}$ & $.375^{* *}$ & $.177^{* * *}$ \\
\hline Student union & & & & & $.243^{* *}$ & $.296^{* *}$ & $.215^{* *}$ & \\
\hline $\begin{array}{l}\text { Humanitarian } \\
\text { org }\end{array}$ & & & & & & $.700^{* *}$ & $.454^{* *}$ & $.352^{* * *}$ \\
\hline $\begin{array}{l}\text { Environmental } \\
\text { org }\end{array}$ & & & & & & & $.517^{* *}$ & $.251^{* *}$ \\
\hline
\end{tabular}

**. Correlation is significant at the 0.01 level (2-tailed).

*. Correlation is significant at the 0.05 level (2-tailed). 